НАУКОВИЙ ВІСНИК

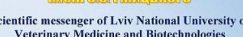

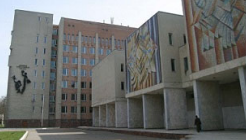

СЕРЯЯ: ВЕЕЕРИНАРНН НАУКИ

RIES: VETERINARY SCIENC
Науковий вісник Дьвівського національного університету ветеринарної медицини та біотехнодогій імені С.З. Гжицького. Серія: Ветеринарні науки

\author{
Scientific Messenger of Lviv National University
} of Veterinary Medicine and Biotechnologies. Series: Veterinary sciences

UDC 637.074: 637.54

\title{
Safety of poultry meat in accordance with EU requirements in Ukraine: state monitoring of hormones
}

\author{
O. M. Chechet ${ }^{1}$, O. M. Berhilevych ${ }^{2}$, V. V. Kasianchuk ${ }^{2}$ \\ ${ }^{1}$ State Research Institute for Laboratory Diagnostics and Veterinary Sanitary Examination, Kyiv, Ukraine \\ ${ }^{2}$ Sumy State University, Sumy, Ukraine
}

\section{Article info}

Received 09.07.2021

Received in revised form 09.08 .2021

Accepted 10.08.2021

State Research Institute for Laboratory Diagnostics and Veterinary Sanitary

Examination, Volynska Str., 12 Kyiv, 02000, Ukraine.

Sumy State University Sanatorna Str., 31, Sumy, 40018, Ukraine. Tel.: +38-067-892-189-45

E-mail:v.kasyanchuk@med.sumdu. edu.ua
Chechet, O. M., Berhilevych, O. M., \& Kasianchuk, V. V. (2021). Safety of poultry meat in accordance with EU requirements in Ukraine: state monitoring of hormones. Scientific Messenger of Lviv National University of Veterinary Medicine and Biotechnologies. Series: Veterinary sciences, 23(103), 78-87. doi: 10.32718/nvlvet10311

The article presents the results of analysis of the world scientific literature from 2010 to the present and official monitoring studies of poultry meat for hormone content for 2017-2020 to provide scientifically sound information on its level of safety in accordance with modern requirements of risk analysis. The problem of the using of hormones in poultry has arisen on the basis of published research by scientists that hormones can jeopardize the safe consumption of poultry products and thus make these products harmful to human health. According to these scientists, the residual amounts of hormones in broiler meat products can have such adverse effects on human health as the risk of cancer, early puberty for girls and boys and an increase in abortions. Such information raises consumer doubts about the safety of industrial poultry meat and increases their demand for "clean - hormone-free meat products". The results of scientific research and consumer distrust of the absence of hormones in poultry meat have led to the initiation of further scientific research on these chemical residues in the EU and the US. In addition, strict legislation was introduced to ban the use of hormones in poultry, introduced mandatory controls on poultry farms to prevent their illegal use, as well as constant monitoring as a precautionary control by the state. However, many scientists claim that due to the ban on the use of hormones in poultry and the constant monitoring of the use of antibiotics, the results of official monitoring in most cases indicate safe levels of these substances in poultry meat. Despite the fact that in 1996 in the EU all hormonal stimulants are officially banned for use by animals and poultry other than for therapeutic purposes, there are scientific publications on the violation of these requirements. There is no ban on hormones in poultry at the legislative level in Ukraine yet. Ukrainian consumers are worried about the safety of poultry meat in terms of hormone content, but producers of large poultry farms assure them that poultry is raised without the use of any growth hormones. In accordance with EU requirements, Ukraine has introduced constant state monitoring of poultry meat content through laboratory control of samples. According to the analysis of the State Monitoring Plans for 2016-2020, there are no risks to the content of hormones in public health when consuming poultry meat. Our data coincide with similar data in most EU countries.

Key words: poultry meat, safety, hormone residues, state monitoring.

\section{Безпечність м'яса птиці відповідно до вимог СС в Україні: державний моніторинг гормонів}

\author{
О. М. Чечет ${ }^{1}$, О. М. Бергілевич ${ }^{2}$ В. В. Касянчук ${ }^{2}$ \\ ${ }^{1}$ Держсавний науково-дослідний інститут з лабораторної діагностики та ветеринарно-санітарної експертизи, \\ м. Київ, Украӥна \\ ${ }^{2}$ Сумський державний університет, м. Суми, Украйна
}


У статті наведено результати аналізу світової наукової літератури з 2010 року по даний час та офіційних моніторингових досліджень м'яса птиці за умістом у ньому гормонів за 2017-2020 роки для надання науково обтрунтованої інформації шьодо рівня його безпечності відповідно до сучасних вимог аналізу ризиків. Проблема використання гормонів у птахівництві виникла на підставі опублікованих результатів досліджень вчених про те, щзо гормони можуть поставити під загрозу безпечне вживання продуктів з м'яса птиці та тим самим зробити ці продукти шкідливими для здоров'я людини. На думку цих вчених, залишкові кількості гормонів у продуктах з м'яса бройлерів можуть мати такі несприятливі наслідки для здоров'я людини, як ризик виникнення раку, раннє статеве дозрівання для дівчаток та хлопчиків $і$ збільшення кількості абортів. Така інформація посилює сумніви споживачів про безпеку промислового м'яса птиці, збільшуються їхні запити на “чисті - без гормонів м'ясопродукти”. Результати наукових досліджень та недовіра споживачів щзодо відсутності в м'ясі птиці гормонів сприяло в СС та США ініціюванню подальщих наукових досліджень за цими хімічними залишками. Крім того, було введене жорстке законодавство щодо заборони використання гормонів у птахівництві, запроваджено обов'язковий контроль на птахофермах для запобігання їх незаконному застосуванню, а також постійний моніторинг як запобіжний контроль з боку держави. Проте багато вчених стверджують, щзо завдяки забороні застосування гормонів в птахівництві та постійному контролю за застосуванням антибіотиків результати офіційного моніторингу в більшості випадків свідчать про безпечні рівні вмісту цих речовин у м'ясі птиці. Незважаючи на те, щзо 1996 року в СС всі гормональні стимулятори офіційно заборонені для використання тваринам і птиці, крім терапевтичних иілей, з'являються наукові публікації про порушення цих вимог. В Украӥні поки щуо на законодавчому рівні немає заборони гормонів у птахівництві. Украӥнські споживачі висловлюють занепокоєння щзодо безпечності м'яса птиці за вмістом гормонів, але виробники великих птахофабрик запевняють їх, щзо птичя вирощується без застосування будь-яких гормонів росту. Відповідно до вимог СС в Україні запроваджено постійний державний моніторинг за вмістом у м'ясі птиці шляхом лабораторного контролю зразків. Згідно з аналізом Планів державного моніторингу за 2016-2020 рр. не встановлено небезпек щзодо вмісту гормонів для громадського здоров'я при споживанні м'яса птиці. Наші дані збігаються з аналогічними даними у більшості країн СС.

Ключові слова: м'ясо птиці, безпечність, залишки гормонів, державний моніторинг.

\section{Вступ}

Куряче м'ясо є широкодоступним, відносно недорогим і може мати вирішальне значення для заповнення дефіциту основних поживних речовин, в тому числі мінералів, вітамінів і амінокислот, крім вітаміну C, тому цей вид м'яса відіграє життєво важливу роль в раціоні людини. Світове виробництво і споживання такого м'яса буде продовжувати рости у зв'язку зі збільшенням попиту. Це призвело до широкого використання ряду “стимуляторів росту”. Гормони додаються в раціон з метою підвищення продуктивності тварин за рахунок збільшення швидкості росту, підвищення ефективності перетворення корму, збільшення виживання і зниження смертності домашньої птиці (Farrel, 2014; Salata, 2018; U.S. FDA, 2019; Nasrin et al., 2020).

Сучасний споживач цінує куряче м'ясо за його доступність, смак, легкість у приготуванні, харчову цінність. Але при цьому споживач часто не до кінця впевнений у його безпечності, особливо щодо вмісту залишків гормонів та антибіотиків. Тому особливо актуально приділяти увагу питанню безпеки м'яса птиці для вживання в їжу людиною (Hemmat et al., 2018; Kukhtyn et al., 2020; Mela et al., 2021).

На думку деяких вчених, гормони можуть поставити під загрозу безпечне вживання продуктів 3 м'яса птиці й тим самим зробити ці продукти шкідливими для здоров'я людини. За останні 25 років спостерігається підвищений споживчий попит на продукти 3 м'яса птиці без додавання гормонів росту. Споживачі хочуть знати більше про м'ясо, яке вони купують, i багато виробників та переробників тепер намагаються задовольнити зростаючу кількість споживачів, які бажають купувати м'ясо і продукти з м'яса птиці, які не містять шкідливих забруднювачів (Hemmat et al., 2018).

Актуальність теми. Сьогодні застосування гормонів строго контролюється у багатьох державах: в США, Канаді, в країнах $С С$ та інших. У цих країнах на державному рівні встановлюються стандарти для застосування гормонів, щоб вони не становили загрози для населення. Для цього в цих країнах проводиться державний моніторинг і тестування харчових продуктів, щоб гарантувати їх відповідність нормативним вимогам (Yang et al., 2020).

З 1996 року в СС всілякі гормональні стимулятори офіційно заборонені для використання тваринам i птиці, крім терапевтичних цілей (Council Directive 96/23/EC, 1996; EU/EC, 2010; Liniichuk, 2018; U.S. FDA, 2019). В Україні поки що на законодавчому рівні немає такої заборони та немає належного контролю за використанням гормональних препаратів при вирощуванні птиці (Baiier et al., 2017; Liniichuk \& Novozhytska, 2017; Liniichuk \& Yakubchak, 2018). Водночас у науковій літературі є дані про те, що деякі виробники практикують неправильне використання гормонів у птахівництві. Їх залишки на даний час трапляються в м'ясі та м'ясопродуктах у різних частинах світу, що значно збільшує ризик негативного їх впливу на здоров'я людей, особливо дітей.

3 іншого боку - проблема використання гормонів у птахівництві посилюється через певні сумніви споживачів про безпеку промислового м'яса птиці та збільшуються їхні запити на "чисті - без гормонів м'ясопродукти”. Недовіра споживачів щодо відсутності в м'ясі птиці гормонів спонукало в СС ініціювати наукові дослідження за цими небезпечними хімічними залишками та було введене жорстке законодавство щодо їхнього використання, а також введено обов'язковий контроль за їхнім застосуванням на птахофермax, в тому числі постійний державний моніторинг як запобіжний контроль якості харчових продуктів 3 боку держави (Plan derzhavnoho monitorynhu, 2017; Hemmat et al., 2018).

Отже, з огляду на можливість неправильного використання гормонів у птахівництві, а також можливість їхнього негативного впливу на здоров'я людей та враховуючи недовіру частини споживачів до безпечності м'яса птиці, є актуальним надання наукової 
інформації про реальний вміст у м'ясі птиці цих хімічних залишків, у тому числі офіційних даних моніторингу.

Метою даного дослідження було проведення аналізу світової наукової літератури, а також аналіз офіційних моніторингових досліджень м'яса птиці за вмістом у ньому гормонів за 2017-2020 роки для надання науково обгрунтованої інформації щодо рівня його безпечності.

\section{Матеріал і методи досліджень}

У статті застосували методологію аналізу літературних даних. Матеріалом служили результати наукових даних, опубліковані в статтях у відкритому доступі в Інтернеті в більшості з PubMed, при цьому використовували ключові слова для пошуку, які відображають тематику даної статті. Пошук літературних джерел проводили 32010 року по даний час. Також надано аналіз результатів виконання Плану щорічного державного моніторингу залишків гормонів у м'язах та печінці курей за період від 2016 до 2020 років, які були проведені на базі Державного науководослідного інституту з лабораторної діагностики та ветеринарно-санітарної експертизи.

\section{Результати та їх обговорення}

Птахівництво стало одним із найбільш економічно привабливих та конкурентоспроможних видів агробізнесу, про що свідчить стійка динаміка зростання виробництва м'яса птиці і яєць в усьому світі. Відомо, що ця галузь є однією з найбільш скоростиглих галузей тваринництва, що забезпечує швидкий оборот вкладених коштів та динамічний іiі розвиток завдяки диверсифікованому типу виробництва продукції. Породи курей сьогодні більш рентабельні, а термін, необхідний для вирощування курчат до товарної категорії, скоротився вдвічі до менш ніж 7 тижнів проти 16 тижнів. I тому на вирощування сучасної курки потрібно менше у 2 рази кормів (Polehenka, 2019; Yatsiv, 2021).

У харчовому ланцюгу виробництва м'яса птиці можуть бути небезпечні забруднювачі в результаті впливу залишків ліків, використовуваних в їхньому виробництві, а також інших забруднювачів навколишнього середовища. Ці забруднювачі можуть поставити під загрозу безпечне вживання продуктів з м'яса птиці і тим самим зробити ці продукти шкідливими для здоров'я людини. Понад 90 \% впливу шкідливих забруднювачів на людину відбувається через вживання забруднених харчових продуктів, включаючи м'ясні продукти. У всьому світі постійно зростає розуміння і заклопотаність з приводу безпеки і споживання м'ясних продуктів для здоров'я людини. Багато забруднювачів, зокерма гормони та антибіотики, що використовуються в як речовин, що сприяють росту тварин і птиці, заборонені в багатьох країнах. Однак вони як i раніше трапляються в м'ясі та м'ясопродуктах у різних частинах світу через бажання фермерів підвищити ефективність виробництва м'яса птиці. Так, наприклад, згідно з офіційним звітом, окремі фермери в Індії використовують гормони та антибіотики у птахівництві для прискорення росту бройлерів, хоча влада заборонила таку практику (Mir et al., 2017). Було виявлено, що деякі птахівники в провінції Шаньдун на сході Китаю використовували надмірну кількість стимуляторів росту своїх курчат, які потім поставлялися великим підприємствам швидкого харчування, що викликало додаткову стурбованість в країні з приводу безпеки харчових продуктів для споживачів (Wang et al., 2013).

Про порушення законодавства щодо застосування гормонів виробниками м'яса птиці в Омані повідомляють Issa та ін. (2020). У м'ясних продуктах бройлерів було виявлено три залишки анаболічних стероїдів (прогестерон, тестостерон i естроген). Залишкові кількості цих анаболічних стероїдів були вищими від максимальних залишкових рівнів (МДР). Залишкові кількості анаболічних стероїдів в продуктах з м'яса бройлерів можуть мати несприятливі наслідки для здоров’я людини і викликати ризик раку, алергію, стійкість до антибіотиків та інші захворювання.

Основними сучасними пріоритетами щодо безпеки харчових продуктів для здоров'я людей $є$ належний контроль за використанням небезпечних сполук при виробництві продовольчої сировини, а також моніторинг їх залишкових кількостей на рівні держави (Abdelrazzag et al., 2016; Liniichuk, 2018). Згідно 3 даними Комісії Codex Alimentarius (CAC), безпека харчових продуктів - це гарантія того, що харчові продукти не заподіють шкоди споживачеві, якщо вони приготовані і / або з’їдені відповідно до їх передбачуваного використання. 3 цієї причини необхідно використовувати різні ресурси для запобігання забрудненню харчових продуктів на всіх етапах харчового ланцюга, від “ферми до споживання”. Хвороби харчового походження виникають в результаті вживання забруднених небезпечними контамінантами харчових продуктів. Забруднення харчових продуктів на будь-якій стадії, від виробництва до споживання, призводить до можливостей виникнення хвороби харчового походження. Ці захворювання $\epsilon$ широко поширеною проблемою охорони громадського здоров'я (Uçar et al., 2016; Mela et al., 2021).

Багатьма дослідниками вивчалися такі два основних небезпечних залишків хімічних речовин в м'ясі птиці: 1) гормони, які сприяють більшому розвитку мускулатури; 2) антибіотики, які використовується для підтримки здоров'я птиці при промисловому іï виробництві. Гормони й антибіотики все ще використовуються в деяких країнах у м'ясній промисловості для управління ростом та розвитком тварин і птиці. Застосування їх пояснюється тим, що ці речовини можуть збільшувати рентабельність м'ясної промисловості.

У даній статті ми приділимо увагу гормонам, тому що дані літератури і судження споживачів останнім часом сповнені стурбованості з приводу безпеки цих речовин в м'ясі птиці для здоров'я людини.

Гормони - це хімічні речовини, які відіграють важливу роль у фізіологічному функціонуванні людини 
та тварин. Гормони поділяють на стероїди або білки, які природним чином виробляються в тварин та людей. Таким чином, природні гормони присутні у всіх людей і тварин, а також і в рослин. Гормони можуть вироблятися в невеликих кількостях в організмі, але вони виконують важливі функції, такі як зростання, розвиток і розмноження (USDA ARS, 2018; U.S. FDA, 2019; Palacios et al., 2020).

Кількість більшості природніх гормонів в організмі людини та тварин мають рівні від пікограмів до мікрограмів, що є дуже низьким рівнем порівняно 3 іншими компонентами харчових продуктів, такими як мікроелементи в їжі (тобто вітаміни і мінерали). Тварини виробляють гормони, аналогічні людським, i тому продукти тваринного походження, наприклад молочні, м'ясні, можуть містити гормони, аналогічні тим, які виробляються людиною. Крім того, кількість власних ендогенних гормонів, які виробляються в організмі людини щоденно в сотні або тисячі разів більша, ніж їх кількість, яка споживається 3 їжею протягом дня. Такі гормони, як прогестерон і естрогени, є жиророзчинними, тому продукти з низьким вмістом жиру містять знижені рівні цих гормонів (Palacios et al., 2020).

Стероїдні гормони мають дві життєво важливі дії: анаболічну і андрогенну. Деякі натуральні або синтетичні стероїди (тестостерон, прогестерон, естрадіол, метилтестостерон і андростендіон) широко використовувалися у м'ясних тварин і птиці для регулювання обміну речовин, анаболічного ефекту і прискорення збільшення ваги. Важливо зазначити, що стероїдні гормони активні в організмі при їх попаданні всередину. Наприклад, протизаплідні таблетки - це стероїдні гормони і їх можна приймати всередину.

Навпаки, білкові гормони розщеплюються в шлунку і втрачають здатність діяти в організмі при їх поїданні. Наприклад, інсулін - це білковий гормон. Пацієнтам 3 цукровим діабетом необхідно вводити інсулін для лікування і не можна застосовувати всередину у вигляді таблеток. Отже, зазвичай білкові гормони необхідно вводити в тканини організму, щоб отримати ефект.

Ця інформація дуже важлива для того, щоб прояснити споживачам, коли вони обговорюють використання гормонів в м'ясі птиці та коли вони мають на увазі додавання синтетичних гормонів росту в процесі iii вирощування. Як імплантування гормонів, так і згодовування їх птиці $є$ кошторисним і трудомістким, хоча вони кілька десятиліть тому використовувались у птахівництві дуже активно в деяких країнах, наприклад США. На даний час використання гормонів росту незаконне для домашньої птиці та свинини в більшості країн світу, а також для молочної худоби. Але ще існує практика використання гормонів росту виробниками м'ясної худоби в деяких країнах, але залишкові рівні цих гормонів ретельно регулюються і контролюються на державному рівні. Зазвичай фермери використовують гормони для підвищення ефективності своєї діяльності. Такі гормональні добавки прискорюють термін зростання i збільшують загальну м'язову масу тварин, роблячи кожну тварину більш прибутковою за коротший період часу (Hemmat et al., 2018).

Європейська комісія встановила жорстке законодавство, яке забороняє використання всіх гормонів для відгодівлі тварин, за винятком терапевтичного застосування, в 1980 році. Ці гормони повинні бути прописані ветеринарним лікарем, а тварини і домашня птиця мають бути забиті після закінчення встановленого часу виведення $з$ організму цих речовин. 3 1980х років Всесвітня організація охорони здоров'я (ВОО3), Продовольча і сільськогосподарська організація (ФАО) і Міжнародне епізоотичне бюро (МЕБ) почали вивчати безпеку цих гормонів при виробництві м'яса. Результати досліджень вчених свідчать, що надмірна дія стероїдів може бути токсичною для органів (печінки і нирок) і систем, а їх залишки можуть викликати різні захворювання (рак простати, яєчників і грудей) часу (Hemmat et al., 2018).

В Україні поки що на законодавчому рівні немає заборони використання гормонів, але, як заявляють самі фермери, які займаються птахівництвом, на практиці мало хто використовує гормони, оскільки це нерентабельно. Сучасні породи бройлерів за умови правильно організованого догляду самі добре ростуть. Але це тільки заяви фермерів, необхідна офіційна інформація перевірки процесу вирощування м'яса птиці та встановлення фактів наявності чи відсутності гормонів у технологічному процесі, в тому числі у складі кормів.

В СС для ефективного контролю небезпечних хімічних сполук (в т. ч. гормонів) у продовольчій сировині та харчових продуктах було прийнято Директиву Ради 96/23/СС “Про заходи 3 моніторингу певних речовин та їх залишків у живих тваринах та у тваринницькій продукції”. Основною метою Директиви Ради 96/23/СС було виявлення незаконного використання небезпечних хімічних сполук у тваринництві, а також виявлення зловживання дозволеними ветеринарними лікарськими засобами. Директива встановила заходи, що вимагають від європейських держав-членів здійснювати моніторинг небезпечних хімічних речовин та їх залишків не тільки шляхом лабораторного контролю зразків, а й поздовж усього харчового ланцюга (Serikbayeva \& Ospanova, 2016; Nasrin et al., 2020).

У 2017 році в СС запропоновано новий підхід до вирішення проблеми контролю небезпечних залишків в продовольчій сировині та харчових продуктах. Цей підхід встановлено у Регламенті 2017/625/ EU Свропейського парламенту і Ради від 15 березня 2017 р. Цей Регламент встановлює гармонізовані вимоги для контролю на основі оцінки ризику в ланцюзі сільськогосподарської продукції. Оцінка ризику та аналіз ризику є сучасними методологічними підходами для вирішення проблем безпечності харчових продуктів для споживачів. Регламент 2017/625/ EU передбачає посилення офіційного контролю з боку уповноважених органів для попередження, скорочення або виключення ризику від небезпечних контамінантів для людей, тварин і рослин.

314 грудня 2019 року положення Регламенту СС 2017/625 вступили в силу, і з цього часу даний Регла- 
мент скасовує ряд законодавчих актів, що формували раніше так званий “Європейський Пакт гігієни”: Регламент (ЕС) 854/2004, Регламент (ЕС) 882/2004, Директива 89/608/ EЕC, Директива 89/662/ EЕС, Директива 90/425/ ЕЕС, Директива 91/496/ EЕС, Директива 96/23 / ЕС, Директива 96/93/ ЕС, Директива 97/78/ ЕС, Рішення 92/438/ ЕЕС. Контролюючі органи та оператори на всіх етапах виробництва, переробки та розповсюдження харчових продуктів, кормів, тварин і рослин повинні керуватися вимогами Регламенту 2017/625/ EU.

Україна зобов'язується наблизити своє законодавство до такого законодавства ЄС, тому в 2021 році було створено сектор оцінки ризиків при Держпродспоживслужбі, який здійснюватиме аналіз ризиків небезпечних чинників для організму людини на основі наукових висновків експертів.

Стосовно гормонів, варто зазначити, що вони все ще використовуються як стимулятори росту у великої рогатої худоби та овець в деяких країнах. За офіційними оцінками, дві третини великої рогатої худоби, вирощеної в США, отримують гормони (зазвичай тестостерон або естрогени) для прискорення росту. У США існує шість різних видів гормонів, схвалених Управлінням по санітарному нагляду за якістю харчових продуктів і медикаментів (FDA) для використання у виробництві продуктів харчування (м'ясне і молочне тваринництво). До них належать природні жіночі статеві гормони естрадіол і прогестерон, природний чоловічий статевий гормон тестостерон і три штучних гормони: зеранол, тренболона ацетат і ацетат меленгестеріна.

Деякі зі схвалених гормонів в США, наприклад, естрадіол (естроген), прогестерон і тестостерон, природним чином виробляються в організмі людини i тварин протягом всього життя. Ці природні гормони необхідні для нормального розвитку, росту і розмноження. Вчені в США вважають, що люди не піддаються ризику вживання в їжу харчових продуктів від тварин, які отримували ці препарати, тому що кількість додаткових гормонів після їхнього вживання дуже незначна порівняно з кількістю природних гормонів, які зазвичай містяться в м'ясі необроблених гормональними препаратами тварин.

Для гарантування безпечності м'яса від тварин, яким застосовували гормони, в США $є$ обов'язкова вимога, щоб виробники продемонстрували, що кількість гормону, яка залишилася в їстівній тканині тварин після обробки була нижчою за відповідний безпечний рівень. Безпечний рівень - це рівень, що, як очікується, не спричинить шкідливого впливу на людину. Варто зазначити, що в США у птахівництві використання гормонів заборонено.

Незважаючи на суворе регулювання безпечного виробництва харчових продуктів від ферми до столу, з боку вчених висловлюються побоювання з приводу безпеки гормонів у харчових продуктах та їхнього впливу на здоров'я людини. Вчені намагаються вирішити цю складну проблему на основі наукових досліджень. Вміст гормонів у харчових продуктах та їх вплив на здоров'я людей вивчається протягом кількох останніх десятиліть, і результати цих досліджень в Сполучених Штатах і Європі показують неоднозначні та суперечливі результати (Malekinejad \& Rezabakhsh, 2015).

Деякі дослідники вважають, що природні гормони, які містяться в харчових продуктах, безпечні для вживання в їжу людиною. Водночас вони акцентують увагу на тому, що існують обмежені дані про сумарний вміст природних та штучних гормонів у їжі та про наслідки для загального стану здоров'я, якщо їх щоденно споживати (Malekinejad \& Rezabakhsh, 2015).

Дослідження, проведені в США з вивчення впливу гормонів росту, що містяться в м'ясі, на дітей в препубертатному віці показало, що якщо дитина сама ще не виробляє гормонів росту, споживання цих гормонів через м'ясо може привести до статевої зрілості у дитини приблизно на сім місяців раніше. Водночас цими дослідженнями не доведено однозначного зв'язку вживання гормонів 3 м'ясом з раннім статевим дозріванням дітей більш старшого віку, оскільки це може бути пов'язано з рядом інших причин: ожиріння, відсутність фізичних вправ, споживання великої кількості обробленої їжі. Також не доведено, що гормони росту, які містяться в м'ясі, можуть призвести до раку.

Неоднозначність у висновках вчених виникає з того факту, що багато гормонів, які містяться в м'ясних продуктах, природним чином зустрічаються як у тварин, так і у людей, і важко відрізнити синтетичні гормони від природних гормонів в зразках м'яса. Крім того, ефекти від споживання гормонів росту і статевих гормонів через м'ясні продукти можуть бути незначними і виявлятися протягом тривалого часу. Кількість гормонів, що потрапляють в кров людини, також дуже незначна порівняно з кількістю гормонів, які людина виробляє природним шляхом на щоденній основі. Однак, незважаючи на висновки вчених, які були проведені в США, СС заборонив всі гормони в яловичині, а гормон rBGH був заборонений в Японії, Канаді, Австралії та Нової Зеландії (Malekinejad \& Rezabakhsh, 2015).

Іншими дослідженнями було виявлено, що синтетичні стероїдні гормони, які можуть надходити 3 їжею, впливають на ризик розвитку раку у людей (Hemmat et al., 2018).

Науковий комітет СС підтвердив, що використання гормонів як стимуляторів росту великої рогатої худоби становить потенційний ризик для здоров'я споживачів. Дослідженнями встановлено, що існує значна кількість наукових доказів, які свідчать про те, що естрадіол $17 ß$ слід розглядати як повний канцероген, оскільки він має як пухлинно-ініціюючий, так і стимулюючий пухлину ефект. Водночас США продовжують стверджувати, що американська яловичина, отримана від великої рогатої худоби, обробленої затвердженими гормонами росту, не становить ризику для здоров'я населення. Сполучені Штати стверджують, що ця позиція підтверджується “науковими оглядами шести гормонів, які дозволені в США та міжнародними стандартами, що стосуються їх засто- 
сування, та багаторічною історією введення цих шести гормонів великій рогатій худобі з метою стимулювання росту" (Serikbayeva \& Ospanova, 2016).

Оскільки безпосередній вплив гормонів у м'ясі птиці та птахопродуктах на здоров'я людини не завжди можливо ефективно дослідити, вчені проводять дослідження на птиці, результати яких можна певною мірою екстраполювати на людський організм. Так, наприклад, було експериментально підтверджено негативний вплив гормону кортикостерону на печінку бройлерів. У бройлерів дослідної групи реєстрували вищий рівень холестерину в печінці порівняно 3 контрольною групою (Liu et al., 2016).

Були також отримані результати досліджень, які підтвердили деструктивний вплив глюкокортикоїдів (ГК) на печінку бройлерів. ГК - стероїдні гормони, що існують як природні, так і їх синтетичні похідні. 3 кори надниркових залоз різних видів виділено понад 50 стероїдів, але тільки кілька стероїдів відповідальні за вплив кори надниркових залоз на метаболізм вуглеводів, білків і жирів. Дексаметазон (DEX) являє собою синтетичну похідну ГК, основна терапевтична дія якого пов'язана з його протизапальними та імунодепресивними властивостями, тому він використовується у ветеринарії для боротьби із запаленнями або алергією. Таким чином, зловживання кортикостероїдами при вирощуванні тварин і птиці не є рідкістю. Під впливом дексаметазону (DEX) в печінці бройлерів були виявлені геморагії і застійні явища, а гістологічне дослідження печінки показало накопичення ліпідних крапель навколо синусоїдів і центральних вен. Також було встановлено посилення глюконеогенезу, зниження периферичної утилізації глюкози, посилення катаболізму білків, зниження накопичення жиру. Незаконне вживання стероїдів і їх залишки в харчових продуктах можуть негативно вплинути на розумовий та фізичний розвиток дітей і фертильність жінок, викликати рак і пошкодити життєво важливі органи, такі як мозок, печінка, нирки i серце (Abdelrazzag et al., 2016; Nasrin et al., 2020).

Єгипетські вчені провели дослідження щодо виявлення гормональних залишків (17 $\beta$ естрадіолу і зеранолу) на місцевих ринках в курей. Було досліджено 100 зразків курячих м'язів, печінки і нирок, які були відібрані випадковим чином на різних ринках в Сгипті, щоб встановити, чи використовуються ці гормональні препарати місцевими фермерами. Були виявлені ці гормони в досліджуваних зразках, але у кількостях, що не перевищують встановлені нормативи. Найбільші їх кількості були у печінці. Вживання м'яса, що містить естрогенний матеріал, призводить до коливання естрогенних гормонів в організмі людини, особливу небезпеку вони становлять для жінок, які годують немовлят. Постійне вживання цих залишкових кількостей гормонів 3 продуктами птахівництва може викликати раннє статеве дозрівання для дівчаток та хлопчиків, пухлини печінки, карциному і збільшити кількість абортів. Результати досліджень не виключають можливості зловживання цими анаболічними гормонами фермерами як на даний час, так і в майбутньому, тому необхідно регулярно контролювати ці хімічні залишки, щоб запобігти небезпеці для здоров'я населення (Hemmat et al., 2018).

Незвичайний негативний ефект від споживання м'яса із вмістом гормону кленбутеролу був зареєстрований у спортсменів. Використання кленбутерола в Мексиці, Китаї та Гватемалі, (заборонений в США і Свропі) як речовини, що сприяє швидкому росту, в тваринництві (яловичина, свинина, баранина і птиця) призвело до численних позитивних результатів антидопінгових тестів у спортсменів за останне десятиліття. Оскільки спортсмени неусвідомлено вживали м'ясо, що містить кленбутерол, Всесвітнє антидопінгове агентство (ВАДА) встановило нові правила, які вступили в силу з 1 червня 2019 року, щоб враховувати той факт, що джерелом кленбутерола може бути м'ясо. ВАДА випустило спеціальні попередження про цю проблему в Китаї та Мексиці. Кленбутерол негативно впливає на серцево-судинну і нервову ситеми людини.

Для вивчення взаємозв'язку між загальним споживанням м'яса, а також м'яса птиці та захворюваністю 20 поширеними видами раку групою іноземних вчених були проведені дослідження на великій кількості людей. В цих дослідженнях було проаналізовано дані UK Biobank 474996 учасників, які взяли участь в цьому експерименті. Вік учасників був 37-73 роки, i вони не мали раку на вихідному рівні. Протягом середнього періоду спостереження 6-9 років у 28955 учасників був діагностований злоякісний рак. Споживання червоного і обробленого м'яса, а також м'яса птиці в кількості 70-90 г день мало тісний зв'язок 3 більш високим ризиком колоректального злоякісного раку і ризику раку товстої кишки. Інші види раку не були підтверджені як такі, що мають зв'язок із вживанням м'яса (Knuppel et al., 2020).

Оскільки деякі наукові дані свідчать про те, що тривалий вплив низьких доз гормонів може викликати серйозну небезпеку для здоров'я людини, таку як рак, порушення імунної системи, гормональних функцій у вигляді передчасного статевого розвитку у дітей. Не можна ігнорувати той факт, що перевищення рівня гормонів в м'ясі птиці виявляється відносно рідко, але це може бути ризиком для забезпечення охорони громадського здоров'я. Отже, існує потреба в регулярному державному моніторингу цих хімічних залишків у якості запобіжного контролю безпечності харчових продуктів (Hemmat et al., 2018; Mela et al., 2021).

Варто зазначити, що багато вчених стверджують, що в багатьох країнах світу завдяки забороні застосування гормонів в птахівництві, постійному їх контролю за застосуванням, результати офіційного моніторингу в більшості випадків свідчать про безпечні рівні вмісту цих речовин у м'ясі птиці (Hemmat et al., 2018).

Таким чином, ми бачимо, що думки вчених неоднозначні щодо негативного впливу гормонів на організм людини. Але якщо є певні наукові дані про можливі ризики, завжди на рівні держав проводяться запобіжні заходи. Ці заходи включають обмеження або заборону використання, моніторинг за виконанням закону, а також інформування суспільства, щоб люди 
були впевнені в безпеці тих продуктів, які вони споживають.

Щодо вмісту гормонів в м'ясі птиці - споживачі в багатьох країнах вже багато років, у тому числі й на даний час, висловлюють побоювання щодо безпечності м'яса птиці для їх здоров'я. У зв'язку з можливими небезпечними наслідками при вживанні м'яса птиці, споживачів непокоїть вплив гормонів, що використовуються в птахівництві та тваринництві, і вони хочуть знати, як впливають ці гормони на здоров'я людини. Через громадську стурбованість з приводу присутності стероїдних гормонів в м'ясної продукції (червоне i біле м'ясо) використання гормонів було заборонено в ряді європейських країн, наприклад Данії, Німеччини, Італії ще в 1960-і роки (Hemmat et al., 2018).

3 огляду на те, що в багатьох країнах серед споживачів існує думка про небезпеку м'яса птиці в зв'язку 3 вмістом у ньому гормонів, аби сформувати правильну думку споживачів, в різних країнах проводяться опитування споживачів, а також публікуються переконливі докази про реальні рівні цих речовин у м'ясі птиці. Формування правильної громадської думки дуже важливе, оскільки воно відіграє важливу роль для виробників продукції птахівництва, а також для регуляторної політики щодо безпеки харчової продукції в кожній країні (Karasu \& Ozturk, 2020; Karasu \& Ergin, 2021).

В Україні для споживача питання використання гормонів росту вкрай хвилююче і не до кінця зрозуміле. Українські виробники курятини запевняють, що на великих птахофабриках, таких як ТМ “Наша Ряба", птиця вирощується без застосування будь-яких гормонів росту. Вони не використовуються при годуванні і не вводяться в раціон будь-яким іншим способом. Для виробництва закуповують курчат племінних бройлерів порід Кобб і Росс у кращих міжнародних компаній. Ця порода швидко зростає, особливо при тому збалансованому харчуванні. Воно регулюється залежно від віку птиці. Вітчизняні виробники м'яса птиці запевняють споживачів, що в Україні на практиці мало хто використовує гормони, оскільки це нерентабельно. Сучасні породи бройлерів за умови правильно організованого догляду самі добре ростуть. Сучасні курчата-бройлери досягають ваги 2,3 кг вже за 5 тижнів. Змінилися бройлери і зовні, нинішні виглядають міцнішими за своїх попередників, мають сильніші ноги. Це результат розвитку генетики й сучасних технологій.

Національна рада птахівництва в США опублікувала результати національного опитування про сприйняття споживачами виробництва курятини, показавши, що майже 80 відсотків американців помилково вважають, що м'ясо птиці містить додані гормони або стероїди, хоча насправді при вирощуванні курей США не використовуються гормони.
Для підсилення даних вищенаведеного огляду літератури та для інформування про дійсний стан рівня безпечності курятини за вмістом у ній гормонів, ми провели аналіз результатів виконання Планів державного моніторингу за 2016-2020 pр. Плани державного моніторингу затверджуються в Україні щорічно на виконання вимог Законів України "Про основні принципи та вимоги до безпечності та якості харчових продуктів". Метою виконання Плану державного моніторингу залишків ветеринарних препаратів та забруднювачів у живих тваринах і необроблених харчових продуктах тваринного походження є здійснення державного контролю використання ветеринарних препаратів, зокрема правил застосування дозволених ветеринарних препаратів та виявлення заборонених речовин, визначення розповсюдження забруднювачів навколишнього середовища, а також підтвердження здоров'я та благополуччя тварин, безпечності харчових продуктів тваринного походження, які підлягають переробці та споживанню людиною. Виконання Плану державного моніторингу є однією із умов для третіх країн, у тому числі України, щодо отримання права експорту до $€ \mathrm{C}$, а також він виконується для підтвердження відповідності національного законодавства вимогам відповідних Директив ЄС для гарантування безпечності харчових продуктів. Виконання даного Плану було здійснено на сучасному лабораторному обладнанні, в акредитованій лабораторії в Державному науково-дослідному інституті з лабораторної діагностики та ветеринарно-санітарної експертизи. Згідно 3 вищезазначеним планом, в Україні щорічно перелік досліджень м'яса птиці на гормони розширюється. Так в 2016 році перелік гормонів, на які було досліджено м'ясо птиці, становив 7 найменувань, у 2020 році - 18 найменувань. Це свідчить про постійне вдосконалення лабораторної діагностики гормонів у м'ясі птиці для виконання плану державного моніторингу та для забезпечення мінімізації ризиків для громадського здоров'я. Програми моніторингу залишків і забруднюючих речовин повинні постійно оновлюватися та включати речовини, щоб ефективніше здійснювати контроль за безпечністю продовольчої сировини та харчових продуктів.

Тому результатам цих досліджень можна довіряти. Результати проведеного нами аналізу наведені у таблиці 1.

Таблиця 1 свідчить, що кількість досліджуваних зразків на вміст гормонів у м'язах та печінці птиці у 2016-2017 роках була майже на однаковому рівні та становила 120-110 зразків відповідно. У наступні роки кількість досліджуваних зразків значно збільшилась. Так у 2018 та 2019-2020 роках їх кількість була 200 та 340 відповідно. Таким чином, збільшення кількості досліджуваних зразків та збільшення кількості досліджень надають більш достовірну оцінку безпечності вітчизняної курятини для споживачів. 


\section{Таблиця 1}

Динаміка кількості досліджень на виявлення залишків різних груп та видів гормональних препаратів у м'язах та печінці курей, які були проведені при виконанні щорічних Планів державного моніторингу у 2016-2020 рр.

\begin{tabular}{|c|c|c|c|c|c|}
\hline \multirow{2}{*}{$\begin{array}{c}\text { Групи гормонів, що } \\
\text { перевірені }\end{array}$} & 2016 & 2017 & 2018 & 2019 & 2020 \\
\hline & \multicolumn{5}{|c|}{ Об’єкт аналізу, кількість зразків } \\
\hline & Всього проб & Всього проб & Всього проб & Всього проб & Всього проб \\
\hline АІ. СПЛЬЬЕНИ & 40, у тому числі: & 40, у тому числі: & 60, у тому числі: & 60, у тому числі: & 60, у тому числі: \\
\hline Диетилстільбестрол (DES) & Печінка 20 & Печінка 20 & Печінка 20 & Печінка 20 & Печінка 20 \\
\hline Діенострол, гексестрол & Печінка 20 & Печінка 20 & - & - & - \\
\hline Діенострол & - & - & Печінка 20 & Печінка 20 & Печінка 20 \\
\hline Гексестрол & - & - & Печінка 20 & Печінка 20 & Печінка 20 \\
\hline $\begin{array}{l}\text { А3. СИНТЕТИЧНІ } \\
\text { СТЕРОЇДИ }\end{array}$ & $\begin{array}{l}\text { Всього проб } \\
\text { 20, у тому } \\
\text { числі: }\end{array}$ & $\begin{array}{c}\text { Всього } \\
\text { проб 20, у } \\
\text { тому числі: }\end{array}$ & $\begin{array}{l}\text { Всього } \\
\text { проб 20, у } \\
\text { тому числі: }\end{array}$ & $\begin{array}{c}\text { Всього проб } \\
20, \text { у тому числі: }\end{array}$ & $\begin{array}{c}\text { Всього проб } \\
20, \text { у тому числі: }\end{array}$ \\
\hline 19-Нор-Тестостерон & Печінка, 9 & Печінка, 9 & Печінка, 10 & Печінка, 9 & Печінка, 9 \\
\hline 17-Бета-естрадіол & М'язи, 11 & М'язи, 11 & М'язи, 10 & М'язи,11 & М'язи, 11 \\
\hline $\begin{array}{l}\text { А4. ЛАКТОНИ РЕЗОР- } \\
\text { ЦИЛОВОЇ КИСЛОТИ } \\
\text { ЗеранОЛ }\end{array}$ & $\begin{array}{c}\text { Всього проб 20, } \\
\text { у тому числі: } \\
\text { Печінка, } 20\end{array}$ & $\begin{array}{c}\text { Всього проб 20, } \\
\text { у тому числі: } \\
\text { Печінка, } 20\end{array}$ & $\begin{array}{c}\text { Всього проб 20, } \\
\text { у тому числі: } \\
\text { Печінка, } 20\end{array}$ & $\begin{array}{l}\text { Всього проб 20, у } \\
\text { тому числі: } \\
\text { Печінка, } 20\end{array}$ & $\begin{array}{c}\text { Всього проб 20, у } \\
\text { тому числі: } \\
\text { Печінка, } 20\end{array}$ \\
\hline А5. БЕТА-АГОНІСТИ & $\begin{array}{c}\text { Всього проб 40, } \\
\text { у тому числі: }\end{array}$ & $\begin{array}{c}\text { Всього проб } 30, \\
\text { у тому числі }\end{array}$ & $\begin{array}{c}\text { Всього проб 100, } \\
\text { у тому числі: }\end{array}$ & $\begin{array}{l}\text { Всього проб 240, у } \\
\text { тому числі: }\end{array}$ & $\begin{array}{c}\text { Всього проб 240, у } \\
\text { тому числі: }\end{array}$ \\
\hline Клен & Печінка, 20 & Печінка, 10 & Печінка, 20 & Печінка, 20 & Печінка, 20 \\
\hline Сальбутамол & Печінка, 20 & Печінка, 10 & Печінка, 20 & Печінка, 20 & Печінка, 20 \\
\hline Циматерол & - & - & Печінка, 20 & Печінка, 20 & Печінка, 20 \\
\hline Рактопамін & - & М'язи, 10 & Печінка, 20 & Печінка, 20 & Печінка, 20 \\
\hline Зілпатерол & - & - & Печінка, 20 & Печінка, 20 & Печінка, 20 \\
\hline Бромбутерол & - & - & - & Печінка, 20 & Печінка, 20 \\
\hline Кленпентерол & - & - & - & Печінка, 20 & Печінка, 20 \\
\hline Ізоксупрін & - & - & - & Печінка, 20 & Печінка, 20 \\
\hline Мабутерол & - & - & - & Печінка, 20 & Печінка, 20 \\
\hline Мапенетерол & - & - & - & Печінка, 20 & Печінка, 20 \\
\hline тербуталін & - & - & - & Печінка, 20 & Печінка, 20 \\
\hline Рітодрін & - & - & - & Печінка, 20 & Печінка, 20 \\
\hline
\end{tabular}

В усіх досліджуваних зразках м'язів та печінки встановлено позитивні результати за вмістом гормонів, які були на мінімальному рівні в межах фізіологічних залишків (відповідають природному рівню гормонів), що оцінюється як відсутність небезпечних рівнів для здоров'я споживачів. За результатами проведених досліджень не встановлено небезпек від гормонів для громадського здоров'я при споживанні м'яса птиці. Наші дані збігаються 3 аналогічними даними у більшості країн СС.

\section{Висновки}

1. У зв'язку із поширеною думкою споживачів про шкоду гормонів в курятині необхідно інформувати їх, що використання гормонів у сільськогосподарської птиці $є$ незаконним. Існують наукові повідомлення про порушення фермерами на птахофермах законодавства в окремих країнах, але рівні гормонів при цьому у м'ясі птиці в більшості випадків -нижчі, ніж ті, що встановлені на законодавчому рівні.

2. Результати досліджень науковців про вплив гормонів у м'ясі птиці для здоров'я людей є біполярними. Згідно з думкою одних дослідників, навіть невеликі залишкові кількості гормонів в м'ясі птиці при регулярному (щоденному) вживанні можуть призвести до несприятливих результатів для здоров'я людини, викликаючи порушення функцій печінки і нирок та інших систем організму, провокуючи цим такі за- хворювання, як рак простати, яєчників і грудей. Інші дослідники дотримуються твердження, що мінімальні кількості гормонів, які є законодавчо дозволеними, не несуть шкоди здоров'ю споживачів.

3. В Україні виконання Плану державного моніторингу залишків ветеринарних препаратів та забруднювачів у живих тваринах і необроблених харчових продуктах тваринного походження в його частині за вмістом гормонів у курятині, щорічно вдосконалюється, збільшується кількість досліджень та кількість досліджуваних зразків, що підвищує рівень достовірності результатів та сприяє більшому гарантуванню безпечного харчування для споживачів.

4. Результати наших досліджень результатів виконання плану Державного моніторингу за 20162020 рр. щодо умісту залишкових кількостей гормональних препаратів у курятині свідчать про відсутність небезпечних рівнів цих речовин, а отже національна курятина може вважатися безпечною за цими показниками.

\section{References}

Abdelrazzag, E., Aboubaker, G., Abolghait, S., \& ElMahmoudy, A. (2016). Evaluation of boldenone as a growth promoter in broilers: safety and meat quality aspects. Journal of Food and Drug Analysis, 24(2), 284-292. doi: 10.1016/j.jfda.2015.12.001. 
Baiier, O. V., Novozhytska, Yu. M., \& Liniichuk, N. V. (2017). Vyznachennia 70 antybakterialnykh preparativ v m'iazakh skryninhovym metodom za dopomohoiu $\mathrm{RKh} / \mathrm{MS} / \mathrm{MS}$. Rehionalnyi naukovyi sympozium $\mathrm{v}$ ramkakh kontseptsii "Iedyne zdorov'ia". m. Kyiv, 2428 kvitnia 2017 roku: tezy dopovidi. K., 152 (in Ukrainian).

Council Directive 96/23/EC of 29 April 1996 on measures to monitor certain substances and residues thereof in live animals and animal products and repealing Directives 85/358/EEC and 86/469/EEC and Decisions 89/187/EEC and 91/664/EEC.

EU/EC (2010). Pharmacologically active substances and their classification regarding maximum residue limits in foodstuffs of animal origin. Official Journal of European Commissions, 37, 1-72.

Farrell, D. (2014). The role of poultry in human nutrition. School of Land, Crops and Food Sciences, The University of Queensland, St. Lucia 4072, Queensland, Australia, FAO.

Hemmat, M. I., Reham, A. A., Omaima, M. D., \& Asmaa, E. H. (2018). Survey on some hormonal residues in chicken meat, liver and kidneys. Benha veterinary medical journal, 34(2), 23-30. URL: https://bvmj.journals.ekb.eg/article_29409_c5fffd8cb7 9eeb216665e94106030022.pdf.

Kadim, I. T., Al-Amri, I. S., AlKindi, A. Y., Al-Magbali, Khalaf, S. R., Mahgoub, O., Imranul, Q. M., \& Abbas, G. (2020). Residues of Antibiotics Anabolic Steroids Pesticides in Assorted Broiler Chicken Meat and Meat Products Available in Omani Market. EC Nutrition, 15(3), 1-13.

Karasu, K., \& Ergin, Ö. (2021). Effects of Allegations Regarding the Use of Antibiotics and Hormones in Diets on Consumer Perceptions, Attitudes and Behaviors towards Broiler Meat Consumption. Turkish Journal of Agriculture: Food Science and Technology, 9(4), 675-682. doi: 10.24925/turjaf.v9i4.675-682.3914.

Karasu, K., \& Ozturk, E. (2020). Consumer consciousness on broiler nutrition with antibiotics and hormones and its reflection of chicken meat consumption VI. International Congress on Domestic Animal Breeding, Genetics and Husbandry - 2020 (ICABGEH-20), Izmir, Turkey, 25-28.

Knuppel, A., Papier, K., Fensom, G. K., Appleby, P. N., Schmidt, J. A., Tong, T. Y. N., Travis, R.C., Key, T. J., \& Perez-Cornago, A. (2020). Meat intake and cancer risk: prospective analyses in UK Biobank. International Journal of Epidemiology, 49(5), 1540 1552. doi: 10.1093/ije/dyaa142.

Kukhtyn, M., Salata, V., Berhilevych, O., Malimon, Z., Tsvihun, A., Gutyj, B., \& Horiuk, Y. (2020). Evaluation of storage methods of beef by microbiological and chemical indicators. Potravinarstvo Slovak Journal of Food Sciences, 14, 602-611. doi: 10.5219/1381.

Kukhtyn, M., Salata, V., Pelenyo, R., Selskyi, V., Horiuk, Y., Boltyk, N., Ulko, L., \& Dobrovolsky, V. (2020). Investigation of zeranol in beef of Ukrainian production and its reduction with various technological processing.
Potravinarstvo Slovak Journal of Food Sciences, 14, 95-100. doi: 10.5219/1224.

Liniichuk, N. V. (2018). Analiz kontroliu zalyshkiv antybakterialnykh rechovyn $\mathrm{v}$ Ukraini. Veterynarna biotekhnolohiia, 32(2), 322-327 (in Ukrainian).

Liniichuk, N. V., \& Novozhytska, Yu. M. (2017). Osoblyvosti nakopychennia enrofloksatsynu v m'iazakh ta orhanakh kurchat-broileriv. Rehionalnyi naukovyi sympoziumu $\mathrm{v}$ ramkakh kontseptsii "Iedyne zdorov'ia”. Kyiv, 24-28 kvitnia 2017 roku: tezy dopovidi. K., 93 (in Ukrainian).

Liniichuk, N. V., \& Yakubchak, O. M. (2018). Analiz monitorynhu zalyshkovykh kilkostei antybakterialnykh rechovyn hrupy V1 v Ukraini. Kontrol bezpechnosti kharchovykh produktiv. Ukraina - YeS: nevyrisheni pytannia: Mizhnarodna naukovo-praktychna konferentsiia $\mathrm{v}$ ramkakh realizatsii proiektu za pidtrymky prohramy Zhana Mone "Kontrol bezpechnosti kharchovykh produktiv u YeS", prysviachena 120-richchiu Natsionalnoho universytetu bioresursiv i pryrodokorystuvannia Ukrainy, m. Kyiv, 19-20 kvitnia 2018 roku: tezy dopovidi. K., 45-46 (in Ukrainian).

Liu, J., Duan, Y., Hu, Y., Sun, L., Wang, S., Fu, W., Ni, Y., \& Zhao, R. (2015). Exogenous administration of chronic corticosterone affects hepatic cholesterol metabolism in broiler chickens showing long or short tonic immobility. Comparative Biochemistry and Physiology - Part A: Molecular \& Integrative Physiology, 191, 53-58. doi: 10.1016/j.cbpa.2015.09.020.

Malekinejad, H., \& Rezabakhsh, A. (2015). Hormones in Dairy Foods and Their Impact on Public Health - A Narrative Review Article. Iranian journal of public health, 44(6), 742-758. URL: https://www.ncbi.nlm.nih.gov/ pmc/articles/PMC4524299.

Mela, L. P., Balogun, S. T., \& Shamak, B. U. (2021). Inappropriate antibacterial use in layer poultry farms in Gombe Metropolis, Northeast Nigeria, may constitute public health challenges. International Journal of Livestock Production, 12(3), 122-127. doi: 10.5897/IJLP2021.0774.

Mir, N., \& Rafiq, A., Kumar, F., Singh, V., \& Shukla, V. (2017). Determinants of broiler chicken meat quality and factors affecting them: a review. Journal of Food Science and Technology, 54, 1-13. doi: 10.1007/s13197-0172789-z.

Nasrin, S., Marzia, A., \& Kazi, R. (2020). Effects of steroid growth promoter on morphological and biochemical adaptations in liver of broiler. Vet World, 13(11), 2330-2337. doi: 10.14202/vetworld.2020.2330-2337 2.

Palacios, O. M, Cortes, H. N., Jenks, B. H., \& Maki, K. C. (2020). Naturally occurring hormones in foods and potential health effects. Toxicology Research and Application, 4, 1-12. doi: 10.1177/2397847320936281.

Plan derzhavnoho monitorynhu zalyshkiv veterynarnykh preparativ ta zabrudniuvachiv u zhyvykh tvarynakh i neobroblenykh kharchovykh produktakh tvarynnoho pokhodzhennia na 2018 rik. Nakaz Derzhavnoi veterynarnoi ta fitosanitarnoi sluzhby Ukrainy vid 05.12.2017 r. № 472 (in Ukrainian). 
Polehenka, M. (2019). An analysis of the current state of poultry production in Ukraine. Economics, 3, 137143. doi: 10.32702/2306-6806.2019.3.137.

Salata, V. (2018). The problem of control of zeranol - a growth promoter of ruminant in beef. Scientific Messenger of Lviv National University of Veterinary Medicine and Biotechnologies, 20(88), 53-55. doi: $10.32718 /$ nvlvet 8809 .

Salata, V. Z. (2018). Otsinka miasa yalovychyny na naiavnist zeranolu - stymuliatora rostu zhuinykh ta vplyv tekh-nolohii zberihannia na yoho vmist. Naukovyi visnyk veterynarnoi medytsyny: zb. nauk. prats. Bila Tserkva, 1(140), 156-162. URL: https://journals.indexcopernicus.com/api/file/viewByF ileId/679808.pdf (in Ukrainian).

Serikbayeva, A., \& Ospanova, A. (2016). The Effect of hormones on the quality of poultry meat. International journal of current research in biosciences and plant biology, 3(1), 113-121 doi: 10.20546/ijcrbp.2016.301.012.

U.S. FDA Website. Animal \& veterinary, safety and health, product safety information: steroid hormone implants used for growth in food-producing animals. https://www.fda.gov.

Uçar, A., Yilmaz, M. V., \& Çakıroğlu, F. P. (2016). Food safety - problems and solutions, significance, prevention and control of food related diseases. hussaini Anthony Makun. doi: 10.5772/63176.

USDA ARS, Nutrient Data Laboratory. USDA national nutrient database for standard reference, legacy. Version current: April 2018. http://www.ars.usda.gov/nutrientdata.

Wang, S., Ni, Y., Guo, F., Fu, W., Grossmann, R., \& Zhao, R. (2013). Effect of corticosterone on growth and welfare of broiler chickens showing long or short tonic immobility. Comparative Biochemistry and Physiology - Part A: Molecular \& Integrative Physiology, 164(3), 537-543. doi: 10.1016/j.cbpa.2012.12.014.

Yang, R., Raper, K. C., \& Lusk, J. L. (2020). Impact of hormone use perceptions on consumer meat preferences. Journal of agricultural and resource economics, 45(1), 107-123. doi: 10.22004/ag.econ.298437.

Yatsiv, S. (2021). State and prospects of poultry development in agricultural enterprises of Ukraine. Agroworld,16, 2633. doi: 10.32702/2306-6792.2021.16.26. 